\title{
A psychophysiolosical study on SHISEIDO esthetic facial massage the relaxation effect of SHISEIDO esthetic facial massage
}

\author{
Tsuneyuki Abe Yukari Suzuki Yuko Hirata
}

The psychophysiological mechanism underlying the efficacy of esthetic facial massage was investigated in two related experiments using subjective, behavioral, and physiological indexes.

In the first experiment, 24 healthy female volunteers ranging in age from 19-21 were assigned to an esthetic massage group (ES) or to a control group (CON) in a mixed design. Each subject was evaluated three times over an interval of several days.

Subjects in Es showed significant changes $(\mathrm{p}<0.05)$ on the subjective index $\mathrm{n}$ terms of reduced tension and increased comfortableness, as assessed on the TAD-ACL (Tohoku ActivationDeactivation Adjective Checklist). Significant sympathetic system changes $(\mathrm{p}<0.05)$ were also observed on the physiological index with a slowing of heart beat after facial massage in the third session.

In the second experiment, 24 naive subjects ranging in age from 19-21 were assigned to 3 equal groups: Es, an autogenic training group (AUT), and CON. Each subject was evaluated 3 times over an interval of several days. Prior to the experiment, subjects were habituated in a single training session. When ES was compared with AUT (Autogenic training is a wellknown relaxation method), significant differences $(p<0.05)$ similar to those in the first experiment were observed on the subjective index in terms of reduced tension and increased comfortableness. The physiological index showed changes in EEG which resembled the stage of suppressed waves seen in the early stage of drowsiness in ES, and which decreased in coherence. These results indicate that esthetic facial massage produces a unique deactivation effect.

These two experiments evaluated the psychophysiological efficacy of esthetic facial massage. Facial massage was shown to reduce arousal level in both the autonomic and central nervous systems and to produce a relaxed mental state which subjects described as "comfortableness".

\section{1. 緒 言}

\section{1 研究目的}

メーキャップ，基礎化粧，エステティックなど，より

㧣資生堂ビューティーサイエンス研究所：品川区西五 反田3-9-1

Shiseido institute of Beauty Sciences: 3-9-1 Nishigotanda, Shinagawa-ku, Tokyo, Japan 141
美しくなるための努力は広く行われて和り，それらの手 法はハード・ソフトとも年々開発されて実に多様化して さている。これらの美容手法は, 自分を他人により一層 美しく見せることを目的とするが，同時にとの行為自体 も目的とされていると考えられる。すなわち, 手段であ る多様な美容手法そのbのが楽しみとされ，特に女性に とって日々の生活の中で欠かすことのできない大切な習 慣亡なっているものと考光られる。 
このような美容手法の 1 つにエステティックマッサー ジがある。エステサロンを訪れる挌客様に, 何故エステ ティックマッサージをらけにいらっしゃったかと尋ねる と「気持らいいから」「やすらぐから」という回答が多 く,エステティックマッサージにはこのような望ましい 心理効果があるということが経験的に言われてきた。し かしこの効果が実験的に確認されたことはなく，その心 理学的なメカニズムは解明されていない。

また, 心理学の領域では不変や恐怖, 痛みといった不 快な状態を喚起する嫌覀刺激 (aversive stimulus) に関 する研究の歴史はあるが，マッサージのような嗜好刺激 (appetitive stimulas) に関する研究は極めて少なかっ た。しかし生活環境の変化に伴い, 喍好刺激の研究に対 する期待はしだいに高まってきている1)。

このような状況に就いて, 本研究は嗜好刺激の一種で あるエステティックフェーシャルマッサージの心理生理 学的な機構への影響を解明することを目的として行われ た。指標は主観指標・行動指標・生理指標の 3 つを用い て総合的に検討した。

\section{2 エステティックフェーシャルマッサージ}

エステティックフェーシャルマッサージは, 刺激とし ては体性感覚 (somatic sensation) 刺激の一種とみなせ る。即らマッサージクリームを用いて專門技術者が指先 で体表を撫で（軽擦・強擦）たり，押し（圧迫）たりす ることによって, 比較的軽度の皮膚感覚を生じさせる刺 激である。この皮膚感覚は触（touch）・圧（pressure） あるいはくすぐったい感じ (tickle) といった機械的刺 激によって扣こるとされる感覚を中心として, 指先の体 温やマッサージクリームによる温 (warm), 冷 (cold) を含もかなり複雑な感覚と言えよる。マッサージ技法と しては上記の他にこねる(柔撚), 吒く(吒打), 震わせ る(振せん), 関節・筋肉学屈伸する（運動）などがあ るが今回の実験では用いられていない。

マッサージが上記のように多様な技法により複雑な感

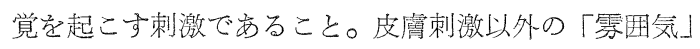
なども影響を与えている可能性があることなどから、マ ッサージ刺激を厳密に統制することは難しい。このマッ サージ刺激学圧拟上って定量化する試及电行われ, 熟 練した技術者ほほとんど一定の手技圧を保つことが報告 されている2゙が，本研究では熟練した技術者は常にほぼ 一定の刺激量のマッサージ施術ができるとみなし，施術 技法を資生堂式フェーシャルマッサージに限定すること 化より, 以下の項目を定性的に統制した。

(1) 刺激部位
（顔・盲筋・肩。脳波等の測定上の都合で耳染・増 帽筋部への施術は省いた）

(2) 刺激方法

(軽擦 (螺旋・往復等) ・王迫（アリキュラ・目頭 等)

(3) 施術順序


又の圧迫）

\section{2. 実験 I（'85年11月）}

実験「では,フェーシャルマッサージによって生じる 心理生理学的反応はいかなるもの杂検討する。

\section{1 方 法}

\section{1 .1 被験者}

宮城学院女子大学の学生 24 名。全て女性で19～21歳。 エステ群と統制群にそれぞれ12名ずつ配した。被験者は アンケートによってアレルギーのないこと, エステ末体 験であること，使用化粧品数が一定基準以上で化粧意欲 が高いこと (化粧度 $H)^{3)}$ ，スケジュールがあらことなど を条件に選択された。

\section{1 .2 装 置}

生理指標測定時は被験者に一定環境の防音シールドル ーム $\left(25^{\circ} \mathrm{C}\right.$ 湿度 $60 \%$ 程度) 内でフェーシャルベッドに 仰臥姿勢で横てわってもらった。その他の測定ほ化粧室 を使用した。

化粧品はオーダレス製品のスキンローション，アスト リンゼントローション，無賦香調製のマッサージクリー ムを用いて香りの影響を極力避けた。

シールドルーム内をモニターし，ビデオ記録するため にビデオデッキとビデオカメラをシールドルーム内部に 設置し，シールドルーム外にモニタ一用ディスプレイを 置いた。

生理指標の記録はデータレコーダ（ウニーマグネスケ ール：NFR-3915）埾使用し，同時にレクチホリー（三 栄湘器 $: 8 \mathrm{~K} 20$ ) に描出した。心拍周期はマイクロコン ピュータ (Sharp：MZ-2000) にてオンライン処理を行 った。脳波は万能2-4現象メモリーオシロスコープ（日 本光電 : VC-10) でモニターし，ヒストグラム解析装置 (日本光電 : DAB-1100) とマイクロコンピュータ) (NEC : PC-9801VM2) を用いて周波数のオフライン分 析を行った。

化粧室には全体的な行動を記録するためにビデオカメ ラを本棚上部に 1 台, 化粧動作を記録するために鏡台の 鏡(ハーフミラー) の裏側に 1 台設置し，ビデオデッキ 
2 台に録画した。

\section{1 .3 指 標}

\section{主観指標}

-TAD-ACL (Tohoku Activation Deactivation Arousal Checklist)：自己報告以よって情動や覚醒水 準の変勳を測定するために開発された，日本語形容詞 チェックリストである4。合計32項目で, 高活性化 (High Activation: HA)

一般的活性化 (General Activation: GA)

一般的脱活性化 (General Deactivation : GD)

脱活性化一睡眠 (Deactivation-Sleep : DS)

の 4 因子で構成される。評定尺度は, 左端学「全く感じ ない」，右端を「非常にはっきりと感じる」とした水平 方向線分 $(10 \mathrm{~cm})$ の visual analog scale とした。評定 值は左端からチェック点ふでの長さ $(\mathrm{mm})$ とした。各 因子の項目を以下泟示。

HA：緊張したびくびくした，緊迫した，そわそわし た, どさどさした

GA：陽気な, 快適な, 元気な, 活動的な, 楽しい, 活 気のある、愉快な, 積極的な, 嬉しい,さわやか な, 機嫌のよい

GD：静かな，平稳な、のどかな、ゆったりした，のん びりしたくつろいだ，和らいだ

DS：うとうとした，痏れた，跟い，だらだらした，く たくたな、だるい

-短縮版 TAD-ALC：上記 TADーACLの4因子から 因子負荷量の高い項目（太字のもの）をそれぞれ3 項 目, 計12項目军選び，短縮版として用いた。評定尺度

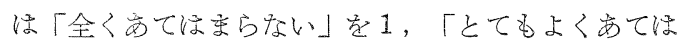
まる」童 7 とした 7 件法である。

-肌状態評定 : 実験終了時, 洗顔後飞肌の状態起自己評 定してもらう。評定尺度は左端を「全く感でない」, 右 端を「非常淿感じる」とした 5 件法である。以下項 目を示す，

(1)肌のさめがこまかくなったようだ

(2)肌にはりがでてきたよらだ

(3)肌がつるつるしてなめらかになったようだ

(4)肌がしっとりしてきたようだ

(5)顔全体の肌色吕白くなってきたようだ

\section{行動指標}

ビデオカメラを用いて以下の行動空記録した。

(1)鏡台で鏡（ハーフミラー）を見ているときの動作表 情

(2)化粧室内でのたちらるまい
(3)シールドルーム内での顔の勉き・表情

このうち鏡台使用時の動作のみを後のデータ解析に用 いた。

\section{生理指標}

-心拍周期：指尖容積脈波を時定数 0.03 秒の交流アンプ によって得た鋭波をR波として以下の手続さで求め た。サンプル

(1)Pre Base (PRE) : 施術期間直前 5 分間

(2) Processing Session (PS) : 施術期間の第 1 セッシ ヨン初頭10分間（5分+5 分）と第 2 セッション初 頭10分間 (5 分 +5 分)

(3)Post Base (POST) : 施術後 5 分間 （処理）各アンプル期間 5 分を30秒ごとの10ブロックに か将る。このうち SD の小さい 3 か所のデータを選 び，その平均值を心拍周期測度とした。

な括統訂的処理にあたってはこれらの值をるとに一 次回帰に上る変換値を求め, 各期間の值とした。

指尖容積脈波：被験者の左手第 2 指から脈波ピックア ップ（日本光電：MPP-3）にて尊出し，時定数 2.0 秒 で堌幅した。このデータを12bit A/D コンバータに より $20 \mathrm{~Hz}$ のサンプリング周期でデジタインズし, 波 高值学算出した。

サンプル

PRE と POST については心拍周期と同様の期間から 中頃の1分をサンプルした。PS については第1 セッシ ョン, 第 2 セッション各々の開始直後 1 分, 中項の 1 分, 終了直前 1 分のか 6 所をサンプルした。

(処理)〔(各ポイント1 分の平均波高值) - (PRE 1 分 の平均波高值) J/(PRE1 分の平均波高値) の式飞従い 各ポイントの変北率を求めた。

- 自発性脳波：国際 10-20 法に準し， Cz (頭頂部）上 り而耳架不関電極として単極尊出し, 時定数 0.3 秒 で增幅した。 サンプル

PRE およびPOST 亿ついて沵心拍周期と同じ期間を アンプル。PS については第1。第 2 セッションとも開 始直後10分間をサンプル。

(処理) データレコーダからの再生出力を0.5 30Hzの バンドパスフィルターを通し，ヒストグラム解析装置 により量子化した。このデータをマイクロコンピュー タによって分析し周波数ヒストグラムを描いた。

・体動：被験者の横わるフェーシャルベッドの腰部底面 に加速度ピックアップ（日本光電：MT-3 T) を取付 け時定数 0.3 秒で導出した。 


\section{1 .4 手続き}

各被験者に同様の実験を 3 回行ったが，各回のインタ 一バルは数日間であった。エステ群と, 統制群の違いは PS 期間にフェーシャルマッサージを施すか否かだけで あり，その際は閉眼安静仰臥姿勢でフェーシャルベッド に横わってもらった。3回の実験はどの回も同じ手順で 行われるが，エステティックの基礎知識の呈示と MPI は1回目にの文施された。 Fig.-1 にエステ群の手順を 示す。

第 1 化粧室期間 (first dressing room period)

エステティックの解説文章黙読 $\rightarrow \mathrm{MPI}$

(ここまで1日目のみ)

$\rightarrow \mathrm{TAD}-\mathrm{ACL} \rightarrow$ 肌状態確認

\section{$\downarrow$}

シールドルーム期間 (shielded-room period)

$\operatorname{PRE}(5 \mathrm{~min}.) \rightarrow$

短縮版 TAD-ACL

$$
\rightarrow \text { スキンローション } \rightarrow
$$

$\mathrm{PS}$ 第 1 セッション (15 min.) $\rightarrow$

短縮版 TAD-ACL

PS 第 2 セッション (15 min.)

$$
\rightarrow \text { 安静 }(3 \mathrm{~min}) \rightarrow
$$

$\rightarrow$ 蒸しタオル

$\rightarrow$ アトリンゼント $\rightarrow$

短縮版 $\mathrm{TAD}-\mathrm{ACL} \rightarrow$

$\operatorname{POST}$ (5 min.)

第 2 化粧室期間 (second dressing room period)

肌状態チェック・評定 $\rightarrow \mathrm{TAD}-\mathrm{ACL}$

Fig.-1. The procedure of experiment I.

-第 1 化粧室期間：被験者が到着するとすず化粧室に入 って座ってもらい，女性実験者が実験の案内をする。 初日には土ステティックに関する知悉度を統制するた め, エステティックの解説文章 ${ }^{5)}$ を読んでもらった。 な扮初日にはこの後 MPI（モーズレイ性格検査；誠 信書房）突実施した。概して外向性得点が高く, 神経 症傾向の低い被験者が多い傾向にあり，ほ法均等に2 群に配された。

初日ではMPIの後, その他の日では化粧公入室後, TAD一ACL でそのときの主観的状態をチェックして
もらった。さらに第 2 化粧室期間での肌状態評定のた めに鏡台で自分の顔を見つめてもらってから、シール ドームに案内した。

・シールドール期間：シールドームに入りガウンに着替 えてもらった後, シャルベッドに横たわってもらい, 男性実験者が電極を装着した。この時点で女性施術者 と女性実験者 (エステ群)，もしくは女性実験者のみ （統制群）が入室し，被験者にしばらく環境に慣れて もらった。内外の連絡はインターホンを介して行っ た。

この後, 安静 (PRE) の生理指標記録を5 分間行っ た。そして女性実験者が短縮版の TAD-ACL 老読み めげ，被験者は口頭で評定值を述べた。

つぎに両群ともスキンローションをコットンで静か に塗布し，PS の第1セッション (15分間) の記録に 入った。このときエステ群にはマッサージを施した が，統制群には何るせず安静にしていてもらった。施 術は資生堂ビューティーサイェンス研究所の熟練専門 技術者が担当した。

PS 第 1 セッションの生理指標記録に続き, 先と同 様の方法で短縮版 TAD-ACL 卆行った。

3 分の安静期間をとり，同様に PS 第 2 セッション （15分）の記録を実施した。乞して両群と寮しタ才 ルで顔を拭きアストリンゼントパッティングをした 後, 短縮版 TAD-ACL 昰行い, 安静 (POST) の記 録を5 分間行った。

ここでシールドルーム内の生理指標記録は終了し， 被験者に着替えてもらい女性実騟者が再び化粧室に誘 導した。

- 第 2 化粧室期間：入室後, 鏡台觉使って肌状態の評定 老行ってもらい最後に TAD-ACL 娄評定してもらっ て実験は終了した。全行程で2時間弱であった。

3 回目の最終日にはこの後詳しく内省報告をしても らい, 謝礼・粗品を渡して, 実験日程は終了する。

\section{2 結 果}

2.2 .1 主観指標

- TAD-ACL：各因子について代表 1 項目の严均評定 值変化をFig.-2〜5に示す。以下因子ごとに結果を記 于े。

HA：1日目ではェステ群, 統制群ともに第 2 化粧室期 間に和ける低下，一なわち処理による評定の低下 が見られた。しかし3 日目では統制群に高なりが 見られた。またエステ群には全体的に処理による 低下が見られた。被験者間 1 要因・被験者内 2 要 




Fig.-2. Mean subjective rating scores of "tense" in the factor High Activation before and after the shieldedroom period on each day.



Fig.-3. Mean subjective rating scores of "comfortable" in the factor General Activation before and after the shielded-room period on each day.

因の枝分れ配置分散分析（2群 $\times 3$ 実験日 $\times 2$ 実 験期間)によると「緊張した」「ときどきした」 の項目に群 $\times$ 実験期間の有意な交互作用が見なれ た $(\mathrm{F}(1 / 16)=8.12, \mathrm{p}<0.01 ; \mathrm{F}(2 / 32)=7.371$, $\mathrm{p}<0.01) 。$ たた緊張した」は群 $\times$ 実験期間の交 互作用子有意だった。

G A : 全期間にわたり，エステ群は処理後に上昇する傾 向があった。「快適な」「元気な」「活動的な」

「楽しい」「愉快な」「嬉しい」「充実した」「活 発な」の各項目に和いて群 $\times$ 実験期間の交互作
OEsthetic group

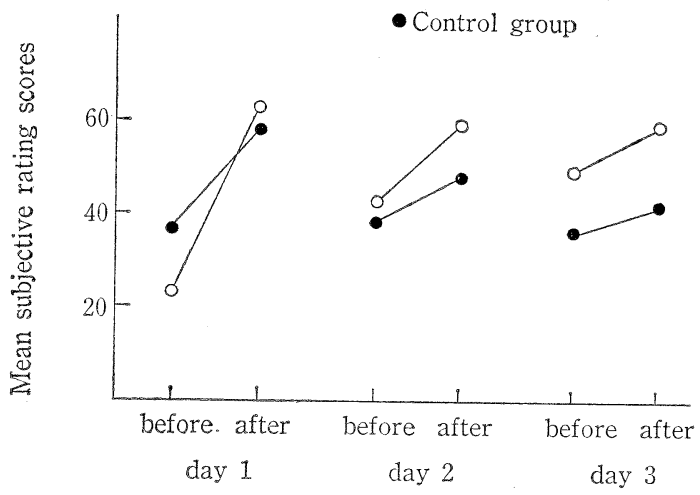

Fig.-4. Mean subjective rating scores of "atease" in the factor General Deactivation before and after the shielded-room period on each day.

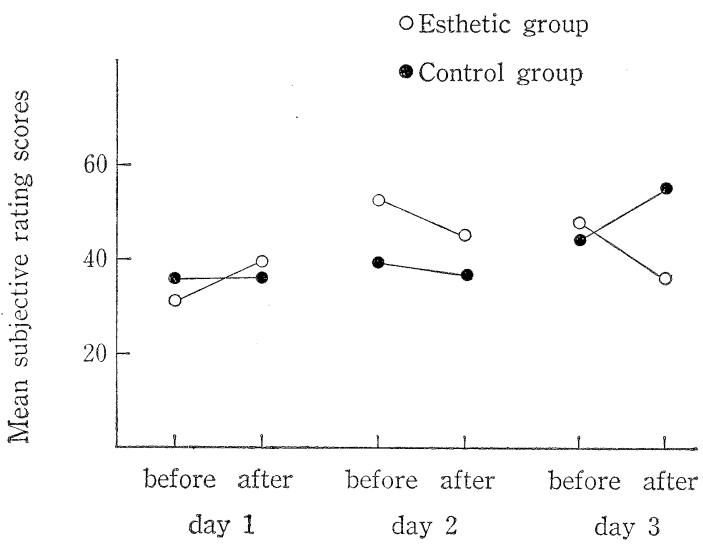

Fig.-5. Mean subjective rating scores of "tired" in the factor Deactivation-Sleep before and after the shielded-room period on each day.

用が有意だった $(\mathrm{F}(1 / 16)=4.737, \mathrm{p}<0.05 ; \mathrm{F}$ $(1 / 16)=6.785, \mathrm{p}<0.05 ; \mathrm{F}(1 / 16)=4.769, \mathrm{p}<$ $0.05 ; \mathrm{F}(1 / 16)=9.096, \quad \mathrm{p}<0.01 ; \mathrm{F}(1 / 16)=$ $11.455, \mathrm{p}<0.01 ; \mathrm{F}(1 / 16)=7.584, \mathrm{p}<0.05 ;$ $\mathrm{F}(1 / 16)=7.464, \mathrm{p}<0.05 ; \mathrm{F}(1 / 16)=5.975$, $\mathrm{p}<0.05) 。$ 統制群には一貫した傾向は見られなふ った

GD：両群ともに処理による上昇が見られた。「のどか な」「ゆったりした」「のんびりした」「くつろ いだ」「和らいだ」では実験期間の主效果が有意 
だった（F $(1 / 16)=17.609, \mathrm{p}<0.01 ; \mathrm{F}(1 / 16)$ $=18.917, \mathrm{p}<0.01 ; \mathrm{F}(1 / 16)=19.214, \mathrm{p}<0.01$; $\mathrm{F}(1 / 16)=22.436, \mathrm{p}<0.01 ; \mathrm{F}(1 / 16)=19.896$, $\mathrm{p}<0.01)$ 。

D S : GD因子と同様に，「らとうとした」「眠い」で は両群とも処理後に上昇が見られ，実験期間の主 効果が有意だった $(\mathrm{F}(1 / 16)=23.121, \mathrm{p}<0.01$; $\mathrm{F}(1 / 16)=7.776, \mathrm{p}<0.05) 。$

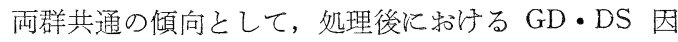
子の上昇並びにHAの低下（実験初日）が見られた。ま た HAの3日目・GA では群間差が見られた。

以上よりエステ群では処理後に, 緊張感の低下に伴ら

「快」の主観状態が生じていたと解される。

Fig.-2 5 TAD-ACL の処理による変化

-短縮版 TAD-ACL：上記 TAD-ACL とほぼ同様の 傾向走示した。

- 肌状態評定：両群の各項目の平均評定值を Fig.-6 に 示す一貫してエステ群の方が評定值が高かった。被験 者間 1 要因・被験者内 2 要因の枝分机配置分散 分析 ( 2 群 $\times 3$ 実験日 $\times 5$ 項目を行ったところ, 群並びに 項目の主効果が有意であった（群 : $F(1 / 17)=16.073$, $\mathrm{p}<0.01$; 項目 : F $(4 / 68)=58.523, \mathrm{p}<0.01)$ 。

統制群は肌の変化が流とんど感じられていないのに 対し，エステ群ではマッサージによる肌の改善が実感 されていたと考光られる。

\section{2 .2 行動指標}

\section{- $\mathrm{LT} \cdot \mathrm{GF} \cdot \mathrm{TF}$ :}

・鏡台に座っていた時間に占める，鏡を見ていた時間の 割合 ; (LT/TT)

・TT30 秒あたりの，身を乗出して鏡を見た回数；(GF $\times 30 \div$ TT)

・TT30 秒あたりの，手で顔に触れる行動の発現回数; $(\mathrm{TF} \times 30 \div \mathrm{TT})$

を測度とした。

これらは両群とも第 2 化粧室期間で值が増える傾向か゚ 見られたが，統計的に有意な差はなかった。

シールドルーム期間での表情記録では特定の傾向は見 出せなかった。

\section{2 .3 生理指標}

比較的明確な差のあったものを示す。

○心拍周期：体動ノイズなどによりデータ化不可能な被 験者を除き，各群 7 名を検討の対象とした。

* POST の変化 : POST の変換值から PRE の変換值 を引いて変換差異得点を求めた。枝分机配置の 2 要因の
ANOVA（2群× 3 実験日）を実施した結果, 群の主效 果と交互作用が有意だった $(\mathrm{F}(1 / 12)=5.21, \mathrm{p}<0.0$ ； $\mathrm{F}(2 / 24)=8.65, \mathrm{p}<0.01)$ ○ステ群では実験日の関数 として心拍周期が増加するのに対し, 統制群では逆に減 少することそ Fig.-6 は示している。実験 3 日目の両群 間の差は有意であった $\left(\mathrm{t}^{\prime}=3.20, \mathrm{df}=6 / 6, \mathrm{p}<0.05\right) 。$

これから実験 3 日目に和いて, エステ群ではマッサー ジによって心拍が遅くなるのに対し, 統制群では逆の傾 向がみられた。これはフェーシャルマッサージが自律神 経系に抑制的に作用したことを示すと考光られる。即ら フェーシャルマッサージには，「鎮静効果」があるもの と考光らる。

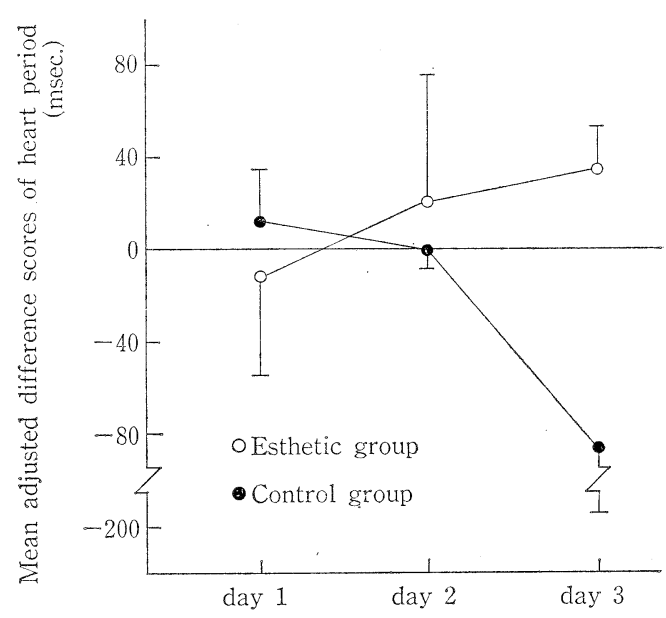

Fig.-6. Mean adjusted difference scores (POST-PRE) of heart period as a function of day. Vertical lines in each plot denote SD.

-脳波：両群とも $\alpha$ 帯域が優勢であり，安静状態が確保 されていたようであるが，処理により $1 \sim 2 \mathrm{~Hz}$ 程度 の徐波化・速波化が見られた。心拍周期に差の方った 3 日目のデータでは, 統制群では速波化を示す被験者 が多く徐波化した者はいなかった。これに対し, エス テ群では徐波化を示した者がデータ化された 7 名中 2 名いた。自律神経系の鎮静化と関連した変化の可能性 がある。

\section{3. 実験 II（'86年11月）}

実験「の結果からはエステティックフェーシャルマッ サージによって自律神経系を中心とした鎮静効果がもた らされることが示唆された。ストレス詨策・リラクゼー 
ション法として広く行われている自律訓練法との比較に よってこの鎮静効果を吟味することを本実験の目的とす る。

\section{1 方 法}

概神実験Ｉと同じ方法をとるが，フェーシャルマッサ —ジを行らエステ群, 自律訓練法を行ら自律訓練群, 何 もせずに仰臥姿勢をたもつ統制群の 3 群を和いた。被験 者 1 名につき数日のインターバルを䗆いて計 4 日間実験 艾行った。ただし初日は全ての被験者について実験環境 そ慣れるための馴化日とし， $2 \sim 4$ 日目を実験日 $1 \sim 3$ 日目として扱った。

1 回の実験は実験 $\mathrm{I}$ と同様，第 1 化粧室期間，シール ドルーム期間，第 2 化粧室期間で構成される。シールド ルーム期間は PRE 7 分, PS 20分（資生堂式フェーシ ャルマッサージ，自律訓練法，仰臥の処理を各群別に 施す), REST 2 分, POST 5 分から構成され PRE, REST，POST を生理指標サンプル期間とする。

\section{1 .1 被験者} 女子大生 24 名を各群 8 人ずつ配した。

\section{1 .2 装 置}

実験 エにほ核準じる。

\section{1 .3 指 標}

\section{主観指標}

実験 【にほほ汸準じる。

な和肌特態評定省省略し、レプリカによる肌測定を馴 化日と 3 日目の PRE 直前に行った。

\section{行動指標}

時間評定：3秒間と思う時間だけキーを押してもらう作 業。

自己ペースのタッピング：好きなテンポでキーを叨いて もらう作業。

両者ともシールドルーム期間化行い，パーソナルテン ポの指骠とした。

な蛒 PS 期間中の動作発現回数学カウントて，1分西 たりの動作発現率を算出した。

\section{生理指標}

実験 I ほほぼ準じるが，左前䛷外側部の表面筋電位， 左手第 3 指の皮膚温の測定を追加した。

脳波测定は国際10-20法に準じ， Fz (前頭部)，O1・ O2（後頭部左右）から両耳架不関電極として導出し た。これたより脳半球の左右差学調べた。

\section{2 結 果}

\section{2 .1 主観指標}

TADーACL についてはェステ群・自律訓練群で顕著
に「緊張した」の評定が処理後に低下した。委た一般的 活性化,一般的脱活性化, 脱活性化一睡眠の 3 因子は各 群とも概权上昇していた。中でも脱活性化一瞬眠の因子 に関してはエステ群で処理による上昇，実験日を重秝る 度の上昇が目立った。また一般的活性化因子の「楽し い」についてェステ群の処理後の上昇も顕著だった。各 群とも（特にェステ群と自律訓練群）緊張感の低下, 快 適感の增大が認められるが，エステ群に怙いては「うと うと」感 (いわゆる drowsy) の方向への变化が特徴的 だった。

短縮版 TAD一ACL \&同様の傾向を示した。

な特肌特態設定の代わり飞行ったレプリカ肌測定では エステ群の肌改善傾向が認められた (Fig.-7)。

\section{2 .2 行動指標}

時間評定は統制群が最も 3 秒に近く, 次にエステ群, 自律訓練群の順で 3 秒より短くなっている。しかし処理 前後の変化注有意で桜なかった。

自己ペースのタッピングではェステ群で処理によりタ ッピング周期が長くなる傾向がぞの実験日でも一貫して 認められた。このことは主観標に括ける緊張感の低下， drowsy 感の增大といら結果を裏付汗るるのと考光ら机 る。

またシールドルーム期間の動作ほエステ群に祘いて, PS 期間飞滅少した。フェーシャルマッサージが運動を 抑制したものと考光られる。

\section{2 .3 生理指標}

脳波については詨数差異值 $(\operatorname{REST} の \theta \cdot \alpha \cdot \beta$ の各带 域の対数パワ值からそれぞれ PRE の值を引いたるの), コヒーレンス差異值 $(\operatorname{REST} の \theta \cdot \alpha \cdot \beta$ の各帯域のコ ヒーレンス值からそれぞれ PRE の值を引いたるの), パワ比率值 $(\operatorname{REST} の \theta \cdot \alpha \cdot \beta$ の各帯域の対数パワ值 をそれぞれ PREの值で割ったるの）を比較した。な杼 眼球運動々筋電位の混入の著しい被験者老各 1 群名除外 して分析を行った。

๔带域の減少が顕著に認められた（Fig.-8 に 01 の $\alpha$ 対数差異值を示す)。エステ群ではマッサージ処理に よって, $\alpha$ 帯域のパワが著しく減衰し, 同時に $\beta$ 帯域の 滅衰も及られた。これらからは睡眠段階Ｉへの移行以似 ているが，日带域のパワに著しい変化が見られなかった こと（通常睡眠段階Iは $\theta$ 帯域のパワ增も伴う）から， むしろ「うとうとしている」状態：入眠期に近い状態で 岕ったと考克られる。

また $\propto$ 帯域のコヒーレンスが他の群と比較して隇少し た（ $\propto$ 活動の脱同期が生じたとみなせる）ことからる単 
Habituation day day 3
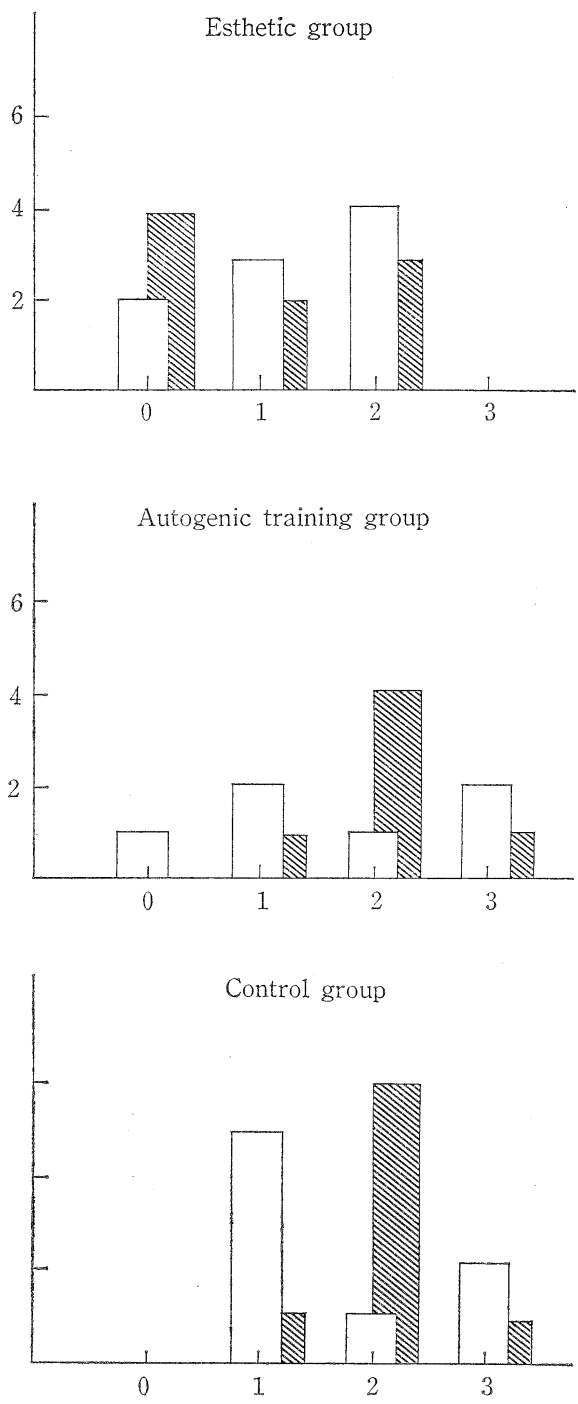

Class of skin surface morphology

Fig.-7. Distribution of skin surface morphólogy judged using the SHISEIDO skin surface image analysis system on habituation day and on day 3 .

In class $O$, furrows and ridges of skin surface are distinct and uniform; in class 3 , they are unclear and irregular.
OEsthetic group

- Autogenic training group $\triangle$ Control group


Fig.-8. Mean power differences (REST-PRE) in $\alpha$ band derived from $\mathrm{O}_{1}$ data on each day.

純な睡眠段階Iへの移行とは考觉られない。しかし主観 指標・行動指標の結果と考皇わせると何らかの覚醒水 準の低下を示するのと解せられる。

\section{4. 考察}

実験 I, 実験II 結果からエステティックタフェーシ ヤルマッサージは

(1)肌状態の改善效果があり，それが塞感される。

(2)常に快適感を伴う。

(3)主観的飞覚醒水準の低下が見られる。

(4)自律神経系, 中枢神経系厄影響し, 脱活性化の作用 を示す。

などの效果を持つことが示された。

これらの効果はいわゆるリラクゼーション效果と言え よう。箺験IIではリラクゼーション效果が大いに期待さ れる自律訓練法との比較を試みたが，脳波を中心として より大きな変化が現れた。だからといって，これから即 エステティックフェーシャルマッサージル自律訓練法以 上のリラクゼーション効果があると断定することはでき ない。しかし 2 種類の実験に和いて一貫して快適感の増 大，覚醒水準の低下・鎮静化の方向への变化が示された ことから, エステティックフェーシャルマッサージはり ラクゼーションの方向に作用して，好ましい心理的效果 を発揮する美粧行為だと解することがでさよう。

この效果が比較的(1)速やかに(2)安定して(3)本人の努力 なしに(4)快適感を味わいながら得られることがエステテ イックフェーシャルマッサージのメリットであらう。慢 性的ストレスに悩又, 肩こり・頭痛などを訴光る女性が 定期的にフェーシャルマッサージ炕よってりラックスを 
獲得することは心理的・生理的に有意義なことと言えよ ら。

この作用の心理生理学的メカニズムは今のところ不明 である。土屋・中山（1987）は麻醉により情動反応（怒 りや恐怖など, 生理的な変化を特徽とする, 強い情緒的 反応：emotion）を抑制したラットを用いて顔面皮膚刺 激による交感神経副婜枝活動の反応を測定し，侵襲性の 刺激（つ季及刺激）は促進的に, 非侵襲性の刺激（ブラ シ刺激）は抑制的に作用するという結果を得た。さらに 反射的な皮膚受容器 $\rightarrow$ 自律神経系モデル沉ついて言及し ている。

一方本研究で示されたように, エステティックフェー シャルマッサージは常沈快適感を伴っている。このよう 飞快適感の認知袁伴ら反応であることからフェーシャル マッサージによる生理心理学的な反応が情動反応だった と考光ることもできよう。

刺激の定量化などを工夫し，施術技法の開発に寄与で きる研究に発展させたい。

注）本研究は杲北大学交学部心理学研究室のスタッフ (丸山欣哉教授・烟山俊輝助教授・平团忠助手( ( 現在 仙台六学講師 $)$ ) - 山田嘉明氏((現在東北大学医学部助 手))・浄土英一氏）上の共同研究であり，1986，1987 日本心理学会の発表をまとめ直したものである。

\section{文 献}

1）湯浅正治(1984)，エステティックマッサージによ る化粧のやすらぎ効果。フレグランスジャ一ナ ル, No. 64, p.42-43.

2) 野村正(1985), 海洋療法の現状と課題。フレグラ ンスジャーナル, No. 73, p. 128-132.

3）岩男寿美子 - 菅原健介 - 松井豊 (1985), 化粧の心 理的効用 $(\mathbb{N})$ : 化粧行動之化粧意議。日本社会心 理会第26回大会研究発表論文集, p. 102-103.

4) 松岡和生 - 畑山俊輝 (1985), Arousal Checklist 作成の試み, 日本応用心理学会第52回大会発表論 文集, p. 89 .

5）土屋徹。中山靖久(1987), 顔面皮虞への機械的刺 激祘よび温度刺激により交感神経副腎枝遠心性放 電活動唀発される反射性反射性反応関する研 究。自律神経, 第 24 巻, 第 1 号, 50-57.

(昭和63年 6 月 1 日受理) 